\title{
FINTECH, BANKS, AND THE COVID-19 PANDEMIC: EVIDENCE FROM INDONESIA
}

\author{
Militcyano Samuel Sapulette*, Nury Effendi**, and Teguh Santoso ${ }^{* * *}$ \\ ${ }^{*}$ Corresponding author. Department of Economics, Faculty of Economics and Business, Universitas \\ Padjadjaran, Indonesia. Email: iansapulette@gmail.com \\ ** Department of Economics, Faculty of Economics and Business, Universitas Padjadjaran, Indonesia. \\ Email: nury.effendi@unpad.ac.id \\ *** Department of Economics, Faculty of Economics and Business, Universitas Padjadjaran, Indonesia. \\ Email: teguh.santoso@unpad.ac.id
}

\begin{abstract}
This study investigates the relationship between fintech and banks and how this relationship is affected by the COVID-19 pandemic. We use monthly stock data of all banks consistently listed on the Indonesian Stock Exchange from February 2018 to March 2021. For fintech data, we use a total of four proxies that encompass both lending and borrowing aspects of peer-to-peer lending fintech. To provide robust results, we use five model specifications. Furthermore, we also estimate models using both the fixed effect and the two-step system generalized method of moments estimators. Our estimates indicate a relatively less negative impact of fintech on bigger banks. This relationship is further exemplified during the COVID-19 pandemic period. We argue that these findings have significant implications for the Indonesian financial authorities' open banking strategy and for the future of the Indonesian financial system in general.
\end{abstract}

Keywords: Fintech; Banks; COVID-19; Pandemic; Stock returns; Indonesia. JEL Classifications: G21; G23; G10.

Article history:

Received : September 25, 2020

Revised : June 04, 2021

Accepted : July 08, 2021

Available online : December 31,2021

https://doi.org/10.21098/bemp.v24i4.1470 


\section{INTRODUCTION}

This study investigates the relationship between fintech and banks and how this relationship is affected by the COVID-19 pandemic. Following the global financial crisis of 2008, fintech has shown tremendous growth and possible disruption to the financial system (Anagnostopoulos, 2018; Buchak et al., 2018). Moreover, the recent COVID-19 pandemic has opened new fintech opportunities. Global interest in fintech lending spiked during the pandemic which coincides with the decline in bank performance (Fu and Mishra, 2020).

Due to complex regulations in the banking industry following the 2008 crisis, banks tend to be less innovative and this disabled banks response time to the innovations put forward by the fintech companies (Anagnostopoulos, 2018). Buchak et al. (2018) showed that regulations on banks accounted for $60 \%$ of the growth of shadow banks (including fintech), while technology accounted for $30 \%$. The increased regulatory burden on traditional banks causes banks to face higher costs and more limited product scope. The 2008 crisis also caused an increase in the public's negative perception of banks (Arner et al., 2015). These unfavorable factors contributed to the emergence of fintech companies.

Technological innovations and internet penetration are also found to be significant factors for the growth of fintech companies. Although beneficial for both banks and fintech, fintech companies have shown themselves better at utilizing these innovations; fintech start-ups are more flexible in adopting technological innovations as they do not operate within the traditional financial ecosystem as banks do (Hornuf and Haddad, 2018). The fintech lending business model allows individuals and companies to lend and borrow directly on the platforms provided by fintech companies. This business model allows lending and borrowing at a lower interest rate than those from banks (Patwardhan, 2018). Besides the lower interest rate, lending and borrowing money using fintech is more "hustle-free" and efficient. Moreover, since fintech companies are not involved in the lending itself but merely act as matches between lenders and borrowers, fintech lending companies are free from the capital requirements that affect the total amount of lending. At the same time, banks are more limited because of these capital requirements (I. Lee and Shin, 2018).

The COVID-19 has further boosted the growth of peer-to-peer lending fintech. Fu and Mishra (2020) showed around 29.2 and 32.8 percent increase in the relative rate of daily downloads of fintech applications during the peak of the pandemic. Peer-to-peer lending fintech has become one of the most viable alternative credit available during the pandemic. Although many banks and financial institutions have offered online loan application services during the COVID-19 pandemic, few have developed verification of loan applications submitted online as effectively as ones developed by fintech companies (Najaf et al., 2021). This increase in the public's interest in fintech is contrary to the performance of banks during the pandemic. Bank stocks have crashed during the pandemic, especially in the early stages of the pandemic. According to Demirguc-kunt et al. (2020), "The crisis and the countercyclical lending role that banks are expected to play have put banking systems under significant stress, with bank stocks underperforming their domestic markets and other non-bank financial firms". The pandemic has also highlighted the urgent need for banks to be at the same pace of technological innovation 
adoption as fintech companies (Wu and Olson, 2020). This phenomena during the pandemic suggest a shift in the relationship between banks and fintech.

Several previous studies have investigated the relationship between fintech and banks. Li et al. (2017) conducted research aiming at clarifying the role of fintech digital banking start-ups in the financial industry. They examined the impact of these start-ups on stock returns of 47 retail banks in the United States from 2010 to 2016 using the Fama- French Three Factor and Five Factors models. They find a positive yet insignificant relation between the growth of the start-ups and incumbent retail banks' stock returns. Jagtiani and Lemieux (2018) studied whether a fintech lending platform could increase credit access to consumers. Using account-level data from LendingClub and Y-14 data reported by banks in the United States, they found that LendingClub's consumers' lending activities have penetrated areas that traditional banks may underserve. Cole et al. (2019) conducted a study by formally testing whether banks are complements or substitutes for crowdfunding. They used comprehensive data on crowdfunding in the United States, which included debt, rewards, donations, and equity crowdfunding. They find that bank failures are associated with a reduction in debt, reward, and total crowdfunding. However, these relations are insignificant. Using a sample of 41 banks from Indonesia from 1997 to 2017 and a two-step GMM estimator, Phan et al. (2019) found that fintech significantly disrupts bank performance and that the effect is larger on large-state-owned banks.

These above-mentioned studies provide mixed results regarding the relationship between fintech and banks. They are also limited, as they only used few proxies for fintech. Furthermore, to the best of our knowledge, the impact of the COVID-19 pandemic on the dynamics between fintech and bank has not been investigated in the literature. This study extends the previous studies by using various proxies of fintech that represent both lending and borrowing aspects of fintech growth. This study also considers the effects of the COVID-19 pandemic on the relationship between fintech and banks. Additionally, we consider the relationship between fintech and three types of banks based on their sizes.

This study uses data from Indonesia. Among emerging market economies, the growth of fintech in Indonesia has been remarkable (Phan et al., 2019). The phenomenal growth of fintech in Indonesia has also triggered several large banks in Indonesia to build partnerships with fintech start-ups or build fintech products of their own (PWC, 2018). The Indonesian financial authorities have also developed a framework of cooperation between fintech, banks, and the digital economy (Bank Indonesia, 2019; Batunanggar, 2019). Furthermore, the effects of the COVID-19 pandemic in Indonesia have been severe. Indonesian banks experienced significant stock decline and increased volatility in the early stages of the pandemic (Mirzaei et al., 2020; Olivia et al., 2020). These facts altogether make the Indonesian case interesting for an empirical exploration.

Our empirical analysis uses monthly stock data of all banks consistently listed on the Indonesian Stock Exchange from February 2018 to March 2021. The banks are classified into three categories based on the sizes of their core capital. For fintech data, we use a total of four proxies that encompass both lending and borrowing aspects of peer-to-peer lending fintech. The data are sourced from the Financial Service Authority Fintech database, Yahoo Finance, and Google. To 
provide robust results, we use five model specifications, namely the Capital Asset Pricing Model (CAPM), Fama-French Three Factor (FF3), and Fama-French Five Factor (FF5) models. We estimate these models using both the Fixed Effect (FE) and the two-step system Generalized Method of Moments (GMM) estimators. To see the dynamics of the relationship between fintech and banks before and during the pandemic, we estimate one of our five models using half-yearly data for each semester from the second semester of 2018 to the second semester of 2020. Our results indicate a relatively less negative impact of fintech on bigger banks. This relationship is further exemplified during the COVID-19 pandemic period. We believe that these findings have significant implications for the Indonesian financial authorities' open banking strategy and for the future of the Indonesian financial system in general.

This paper is organized into five sections. Section II presents our theoretical framework. Section III explains our empirical strategy. Section IV contains the findings and analysis of the findings. Finally, Section V provides the concluding remarks.

\section{THEORETICAL FRAMEWORK}

The relationship between fintech and banks has three possibilities: Competition, cooperation, or independent (Cole et al., 2019; Li et al., 2017).

On the one hand, fintech innovation offers services that may become substitutes for the services provided by traditional banks. Fintech innovation is deemed a form of disruptive innovation, the type of innovation that may reshape the whole industry (Ho et al., 2018). Disruptive innovation can happen if a new entrant in the industry acquires the previously overlooked segment in the industry (Johnson and Christensen, 2000). In fintech, these segments are unbanked and underbanked, such as small and medium-sized enterprises (Arner et al., 2015). Fintech may replace banks in the industry by providing an alternative with lower cost and more efficient services, thus "stealing" banks' customers (Cole et al., 2019; I. Lee and Shin, 2018; Siek and Sutanto, 2019).

On the other hand, the growth of fintech can also benefit banks. One argument for this is that many banks have seen the potential of fintech and tried to incorporate them. Some incumbent banks see fintech more as a benefit instead of a disruption (PWC, 2018). Moreover, fintech companies may also benefit from cooperating with banks since they will get access to banks' customers and the global payment system. Cooperation with banks will also lower barriers to entry for fintech firms to the financial sector and help fintech companies gain more trust from the public (Li et al., 2017). As fintech gains more customers that are previously underbanked or underserved, fintech can also bring more customers to banks, as entrepreneurs tend to seek more than one source of financing (Cole et al., 2019). Furthermore, banks can also improve their efficiency by incorporating technological innovation from fintech companies ( Lee et al., 2021). 


\section{Figure 1. \\ Framework}

This figure summarizes the conceptual framework used in this study. The solid arrows show the assumed transmission of fintech growth to bank stock returns, while the dotted arrows show the possibilities of the relationship between fintech and banks.

Growth of fintech

Possible impact on banks:

- Loss of customers (Li et al., 2017; Cole, Cumming, \& Taylor, 2019; Siek \& Sutanto, 2019);

- Loss of underserved market segments (Arner et al., 2015; Lee \& Shin, 2018);

- Partnership and/or incorporation of fintech (Li et al., 2017);

- Increase in customer as fintech customers seek for other source of financing (Cole et al., 2019);

- Improved performance from fintech technological spillover (Lee et al., 2021);

- $\quad$ No effect (Li et al., 2017; Cole, Cumming, \& Taylor, 2019).

Market response towards bank performance and its future prospect based on fintech growth (Bordalo et al., 2020; Heaton \& Lucas, 1999).

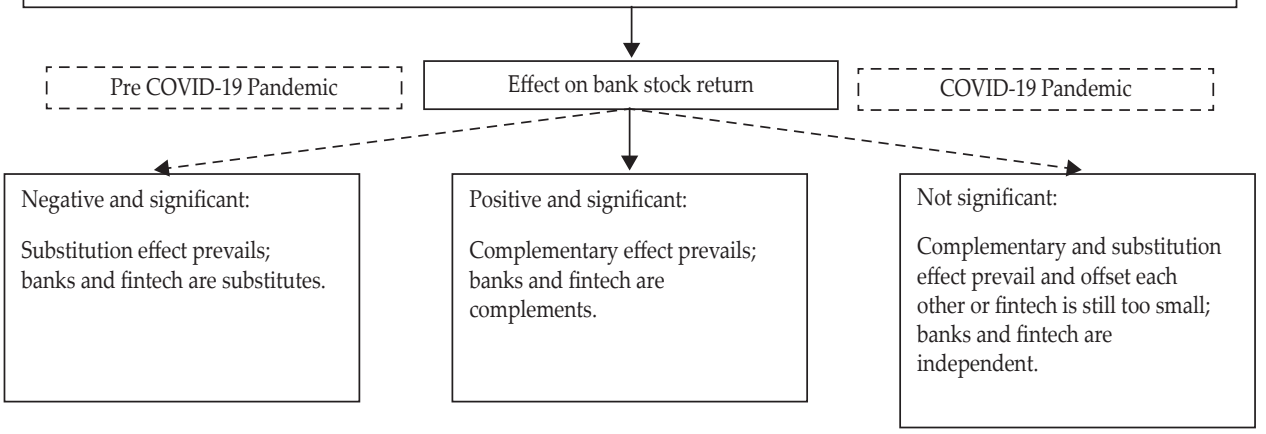

Besides the possibility of bringing significant positive and negative impacts, fintech also has the possibility of not affecting traditional banks. When there is no significant impact observed, Li et al. (2017) argue that fintech might either be too small to affect bank performance, serve completely different segments of customers, or that the positive and negative impacts of fintech on banks offset each other.

We aim to investigate the relationship between fintech and banks and how this relationship is affected by the COVID-19 pandemic. We hypothesize that bank performance is affected by the growth of fintech and that the impact of fintech on banks is captured by banks' stock returns (Bordalo et al., 2020; Heaton and Lucas, 1999). We investigate the impact of fintech on three types of banks based on their sizes. Furthermore, we also analyze how fintech and bank relationships differ preCOVID-19 pandemic and during the pandemic.

We borrow the terminologies used by $\mathrm{Li}$ et al. (2017) to classify the three possible impact of fintech on banks: (1) When the impact is negative and significant, substitution effect of fintech is greater than the complementary effect, fintech and banks are substitutes; (2) when the impact is positive and significant, then the complementary effect of fintech is greater than its substitution effect, fintech and bank are complements; and (3) if there is no statistically significant effect observed, 
then the substitution and complementary effects offset each other or fintech is still too small to affect banks' stock return. Figure 1 summarizes the conceptual framework of this study.

\section{EMPIRICAL STRATEGY}

A. Method

In modeling the impact of fintech on banks, we consider five model specifications. These models are built by modifying the CAPM (Treynor, 1961), FF3 (Fama and French, 1999), and FF5 (Fama and French, 2015) models. We modified them by adding our variables of interest. The five models are represented in Equations (1) to (5) below.

$$
\begin{aligned}
& R F R_{i, t}=\alpha_{0}+\beta_{1} R F M R_{t}+\delta_{1} \text { FINTECH }_{t}+\delta_{2} \text { BIG_FIN }_{i, t}+\delta_{3} M E D_{-} F I N_{i, t}+v_{i, t} \\
& R F R_{i, t}=\alpha_{0}+\beta_{1} R F M R_{t}+\beta_{2} S M B_{t}+\beta_{3} H M L_{t}+\delta_{1} \text { FINTECH }_{t}+\delta_{2} \text { BIG_FIN }_{i, t} \\
& +\delta_{3} M E D_{-} F I N_{i, t}+v_{i, t} \\
& R F R_{i, t}=\alpha_{0}+\beta_{1} R F M R_{t}+\beta_{2} S M B_{t}+\beta_{3} H M L_{t}+\beta_{4} R M W_{t}+\beta_{5} C M A_{t} \\
& +\delta_{1} \text { FINTECH }_{t}+\delta_{2} \text { BIG_FIN }_{i, t}+\delta_{3} M E D_{-} F I N_{i, t}+v_{i, t} \\
& R F R_{i, t}=\alpha_{0}+\beta_{1} R F M R_{t}+\beta_{2} S M B_{t}+\beta_{3} H M L_{t}+\beta_{4} R M W_{t}+\beta_{5} C M A_{t} \\
& +\delta_{1} \text { FINTECH } H_{t}+\delta_{2} B I G_{-} F I N_{i, t}+\delta_{3} M E D_{-} F I N_{i, t} \\
& +\eta \operatorname{GTREND} D_{i, t}+v_{i, t} \\
& R F R_{i, t}=\alpha_{0}+\beta_{1} R F M R_{t}+\beta_{2} S M B_{t}+\beta_{3} H M L_{t}+\beta_{4} R M W_{t}+\beta_{5} C M A_{t} \\
& +\delta_{1} \text { FINTECH }_{t}+\delta_{2} \text { BIG_FIN }_{i, t}+\delta_{3} \text { MED_FIN }_{i, t}+\eta \text { GTREND } D_{i, t} \\
& +\theta_{1} \text { COVID } D_{t}+\theta_{2} \text { BIG_COVID } \text { C }_{t}+\theta_{3} M E D_{-} C O V I D_{t} \\
& +\theta_{4} B I G_{-} F I N_{-} C O V I D_{t}+\theta_{5} M E D_{-} F I N_{-} C O V I D_{t}+v_{i, t}
\end{aligned}
$$

The dependent variable in all five models is the risk-free return of bank stocks. Parameters $\beta_{1}$ to $\beta_{5}$ are the coefficients of the risk-free market return, size factor, value factor, profitability factor, and investment factor, respectively. $\delta_{1}$ to $\delta_{3}$ are the parameters of our primary variable of interest. They are the FINTECH proxies and their interaction with the big bank and medium bank dummy, respectively. The FINTECH variable can be one of the four proxies of fintech growth. $\eta$ is the parameter for the Google Finance ticker search relative trend index for each bank stock (GTREND), which represents investors' attention. This variable has been proven to enhance asset pricing models, especially in emerging economies, and serves as a good proxy for any news regarding stocks (Nguyen et al., 2019; Salisu et al., 2021). $\theta_{1}$ to $\theta_{5}$ are the parameters for the COVID-19 pandemic dummy variable (COVID), and its interaction terms with, big bank dummy, medium bank dummy, big bank dummy and fintech variable, and medium bank dummy and fintech variable, respectively. Finally, $v_{i, t}$ is the composite error term. A complete description of each variable in Equations (1) to (5) can be found in the next subsection (i.e., Section III.B). 
The five models (i.e, Eq. (1) to (5)) are extensions of models developed by Li et al. (2017). We extend their models by introducing the interaction terms between fintech and bank dummy, GTREND variable, and the COVID-19 dummy variable (COVID) along with its interaction terms with the FINTECH variable and bank dummy variables.

We consider two different estimators to estimate these models. We first estimate the models using the fixed effect estimator. We then estimate the same models using the two-step system GMM estimator. In both estimations, we use heteroscedasticity and autocorrelation consistent standard errors. In the GMM estimation specification, an additional one-period lagged dependent variable is added as an independent variable in all models. The one-period lagged of the dependent variable and the GTREND variable are considered endogenous, while the CAPM, FF3, and FF5 are treated as instrument variables.

After estimating the five models using the full data from February 2018 to March 2021, we estimate model four in Equation (4) using half-yearly data for each semester from the second semester of 2018 to the second semester of 2020. We use the two-step system GMM for this estimation. We then obtain the value of $\delta_{1}$ to $\delta_{3}$ to see the changes in the relationship between fintech and banks in these five different time horizons. Our analysis regarding this focuses on the difference between the pre-COVID-19 and during the pandemic periods.

\section{B. Data and Variables}

The data used in this study encompasses 39 banks that are listed on the Indonesian Stock Exchange. The data are in monthly frequency and span from February 2018 to March 2021. There is a total of 46 banks listed on the Indonesian Stock Exchange. Of these 46 banks, 39 banks are consistently listed and have non-constant stock returns for more than six months from February 2018 to March 2021. The 39 banks sampled consist of 36 national banks and three regional banks. The three regional banks operate in the Province of Banten, West Java, and East Java. All banks sampled in this study have customers across Indonesia. Thus, we deemed it not necessary to control for the regions in which the banks operate.

These banks are classified based on the sizes of their core capital, namely big, medium, and small. We utilized the Indonesian Financial Service Authority classification of banks to group banks into these three categories. The Indonesian Financial Service Authority classifies banks based on their core capital in a system called "BUKU". Banks classified as BUKU I are banks with core capital of 100 billion Rupiah to one trillion Rupiah, BUKU II are banks with core capital of more than one to five trillion Rupiah, BUKU III are banks with core capital of more than five to 30 trillion Rupiah, BUKU IV are banks with core capital of more than 30 trillion Rupiah (Financial Service Authority Regulation Number 6 /POJK.03/2016). Due to the small number of BUKU I banks listed on the Indonesia stock exchange, we group BUKU I and BUKU II banks together in our small bank category. BUKU III banks and BUKU IV banks are classified as medium and big, respectively. Details of the banks sampled in this study are presented in the Appendix. 


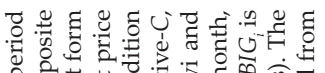

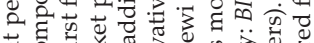

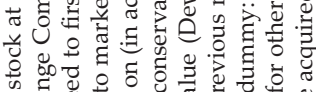

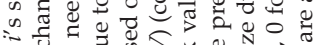

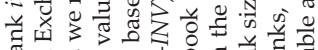

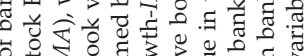

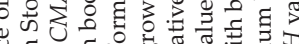

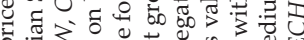
2. 士

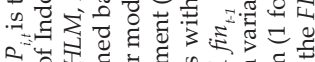
के की

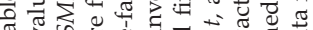
व

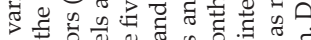

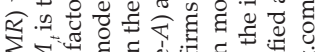

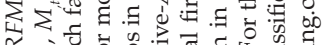

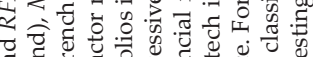

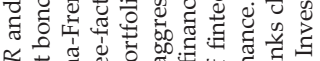

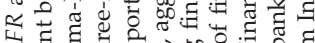
乙记 ن


₹

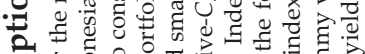

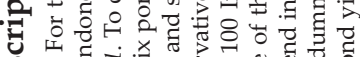

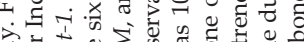

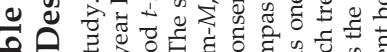

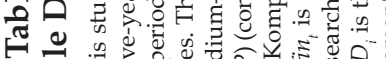

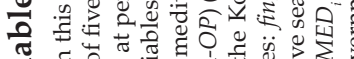

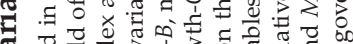

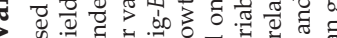
D

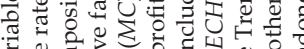
항 멸

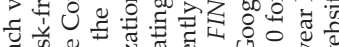
政品

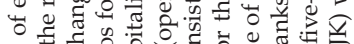

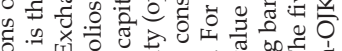

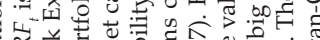

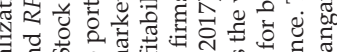
च है क $\infty$ व

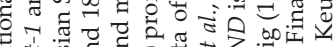

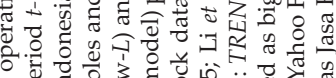

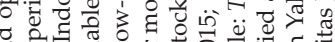

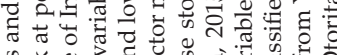
出

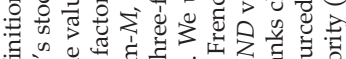

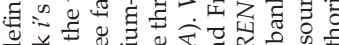

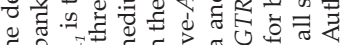

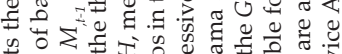

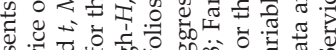

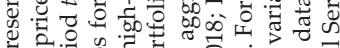

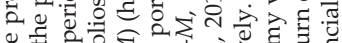

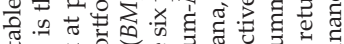

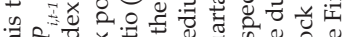

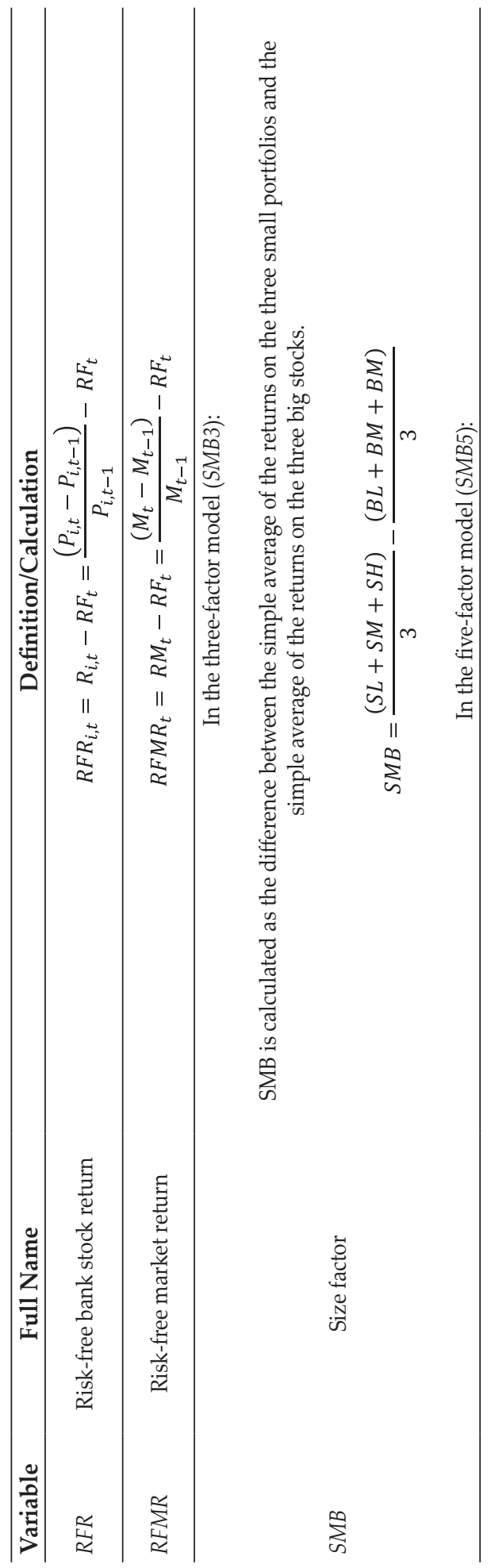









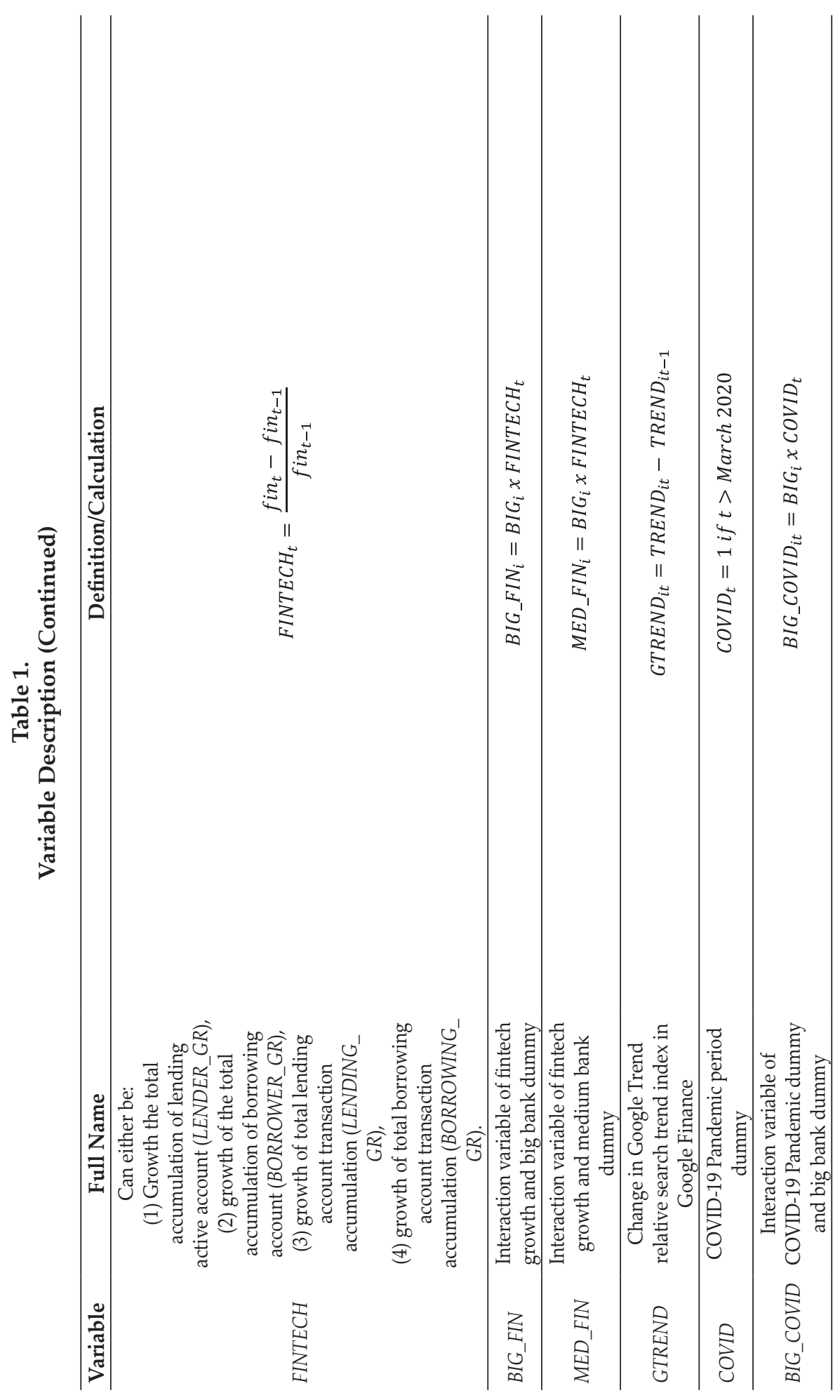




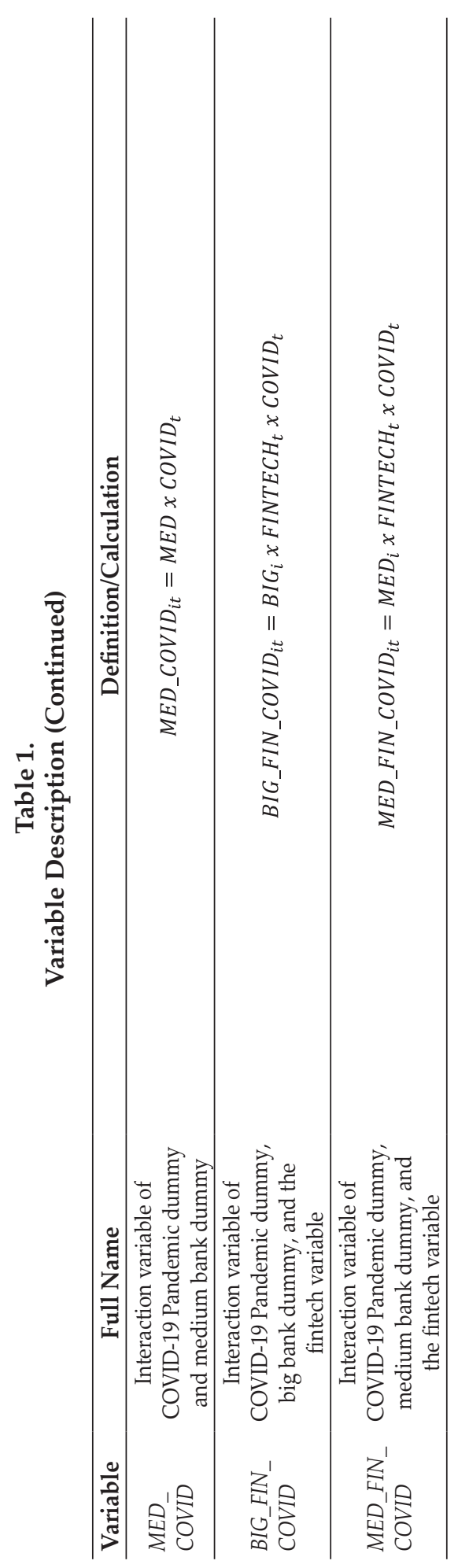


Fintech, in this study, refers specifically to peer-to-peer fintech/fintech lending as defined in Financial Service Authority Regulation Number 77/POJK.01/2016 about peer-to-peer lending/fintech lending (layanan Pinjam Meminjam Uang Berbasis Teknologi Informasi, LPUBTI). The term "peer-to-peer lending" and "fintech lending" bear the same meaning and are used interchangeably. In the regulation, fintech lending is defined as "...technological innovations in finance that allow lenders and borrowers to conduct a transaction without having to meet in person. The transactions are done through platforms provided by fintech companies, either in apps or websites". This definition refers to a specific sub-segment of fintech, the crowdlending segment. Dorfleitner, Hornuf, Schmitt, and Weber (2017) divide fintech into five segments. Crowdlending is part of the financing segment, while the other segments are asset management, payment, and other fintech. Nuryakin, Aisha, Waraney, and Massie (2019) found that this segment is the second largest segment of fintech in Indonesia with a stock of 33\%, below payment fintech (44\%).

We use four proxies of fintech: (1) Growth of the total accumulation of lending active account, (2) growth of the total accumulation of borrowing account, (3) growth of total lending account transaction accumulation, and (4) growth of total borrowing account transaction accumulation. The complete definitions of all these fintech proxies and other variables used in this study are presented in Table 1.

\section{RESULT AND ANALYSIS}

\section{A. Summary Statistics and Stationarity Test}

Table 2 presents the summary statistics of variables used in this study, excluding the dummy variables of bank classification and all interaction variables. The table also presents the Levin-Lin-Chu test for stationarity in panel data (a variable is stationary if $p$-value < alpha). Using a significance level of $5 \%$, all variables used are deemed stationary.

\section{Table 2.}

\section{Summary Statistics and Stationarity Test}

This table reports the summary statistics, and the stationarity test results. Std. Dev. is the standard deviation of the variables, Min is the minimum value, Max is the maximum value, and p-value of LLC is the p-value for the Levin-Lin$\mathrm{C}$ u test for stationarity in panel data. In the Observation column, $\mathrm{N}$ is the total observations, $\mathrm{n}$ is the number of cross-sections, and $\mathrm{T}$ is the number of the time periods. The full name of each variable listed in this table can be found in Table 1.

\begin{tabular}{lllllllll}
\hline & Variable & Mean & $\begin{array}{c}\text { Std. } \\
\text { Dev. }\end{array}$ & Min & Max & Observations & $\begin{array}{c}p \text {-value of } \\
\text { LLC }\end{array}$ \\
\hline RFR & Overall & -0.044 & 0.228 & -0.843 & 3.786 & $\mathrm{~N}=1482$ & 0.000 \\
& Between & & 0.040 & -0.075 & 0.154 & $\mathrm{n}=39$ & \\
& Within & & 0.225 & -1.041 & 3.588 & $\mathrm{~T}=38$ & \\
\hline \multirow{2}{*}{ RFMR } & Overall & -0.068 & 0.048 & -0.228 & 0.040 & $\mathrm{~N}=1482$ & 0.000 \\
& Between & & 0.000 & -0.068 & -0.068 & $\mathrm{n}=39$ & \\
& Within & & 0.048 & -0.228 & 0.040 & $\mathrm{~T}=38$ & \\
\hline \multirow{3}{*}{ SMB3 } & Overall & -0.003 & 0.054 & -0.133 & 0.110 & $\mathrm{~N}=1482$ & 0.000 \\
& Between & & 0.000 & -0.003 & -0.003 & $\mathrm{n}=39$ & \\
& Within & & 0.054 & -0.133 & 0.110 & $\mathrm{~T}=38$ & \\
\hline
\end{tabular}


Table 2.

Summary Statistics and Stationarity Test (Continued)

\begin{tabular}{|c|c|c|c|c|c|c|c|}
\hline \multicolumn{2}{|c|}{ Variable } & Mean & $\begin{array}{l}\text { Std. } \\
\text { Dev. }\end{array}$ & Min & Max & Observations & $\begin{array}{c}p \text {-value of } \\
\text { LLC }\end{array}$ \\
\hline \multirow[t]{3}{*}{ SMB5 } & Overall & -0.005 & 0.051 & -0.135 & 0.140 & $N=1482$ & 0.000 \\
\hline & Between & & 0.000 & -0.005 & -0.005 & $\mathrm{n}=39$ & \\
\hline & Within & & 0.051 & -0.135 & 0.140 & $\mathrm{~T}=\quad 38$ & \\
\hline \multirow[t]{3}{*}{ HML } & Overall & 0.002 & 0.056 & -0.111 & 0.129 & $N=1482$ & 0.000 \\
\hline & Between & & 0.000 & 0.002 & 0.002 & $\mathrm{n}=39$ & \\
\hline & Within & & 0.056 & -0.111 & 0.129 & $\mathrm{~T}=38$ & \\
\hline \multirow[t]{3}{*}{$R M W$} & Overall & -0.022 & 0.084 & -0.237 & 0.120 & $\mathrm{~N}=1482$ & 0.000 \\
\hline & Between & & 0.000 & -0.022 & -0.022 & $\mathrm{n}=39$ & \\
\hline & Within & & 0.084 & -0.237 & 0.120 & $\mathrm{~T}=38$ & \\
\hline \multirow[t]{3}{*}{ CMA } & Overall & 0.006 & 0.071 & -0.203 & 0.177 & $N=1482$ & 0.000 \\
\hline & Between & & 0.000 & 0.006 & 0.006 & $n=39$ & \\
\hline & Within & & 0.071 & -0.203 & 0.177 & $\mathrm{~T}=\quad 38$ & \\
\hline \multirow[t]{3}{*}{ LENDER_GR } & Overall & 0.054 & 0.138 & -0.380 & 0.674 & $N=1482$ & 0.000 \\
\hline & Between & & 0.000 & 0.054 & 0.054 & $\mathrm{n}=39$ & \\
\hline & Within & & 0.138 & -0.380 & 0.674 & $\mathrm{~T}=\quad 38$ & \\
\hline \multirow[t]{3}{*}{ BORROWER_GR } & Overall & 0.160 & 0.194 & -0.411 & 0.889 & $N=1482$ & 0.000 \\
\hline & Between & & 0.000 & 0.160 & 0.160 & $\mathrm{n}=39$ & \\
\hline & Within & & 0.194 & -0.411 & 0.889 & $\mathrm{~T}=38$ & \\
\hline \multirow[t]{3}{*}{ LENDING_GR } & Overall & 0.139 & 0.098 & 0.010 & 0.375 & $\mathrm{~N}=1287$ & 0.000 \\
\hline & Between & & 0.000 & 0.139 & 0.139 & $\mathrm{n}=39$ & \\
\hline & Within & & 0.098 & 0.010 & 0.375 & $\mathrm{~T}=33$ & \\
\hline \multirow[t]{3}{*}{ BORROWING_GR } & Overall & 0.153 & 0.078 & 0.049 & 0.411 & $N=1287$ & 0.000 \\
\hline & Between & & 0.000 & 0.153 & 0.153 & $\mathrm{n}=39$ & \\
\hline & Within & & 0.078 & 0.049 & 0.411 & $\mathrm{~T}=33$ & \\
\hline \multirow[t]{3}{*}{ GTREND } & Overall & 0.274 & 6.967 & -45.000 & 49.250 & $N=1482$ & 0.000 \\
\hline & Between & & 0.428 & -0.211 & 1.908 & $\mathrm{n}=\quad 39$ & \\
\hline & Within & & 6.954 & -44.621 & 48.057 & $\mathrm{~T}=38$ & \\
\hline
\end{tabular}

B. Regression Results and Analysis

Tables 3 and 4 present the regression results for the models estimated using the fixed effect estimator and two-step system GMM estimator, respectively. Only models three to five are included in Tables 3 and 4 . The results of models one and two are in the Appendix.

In models three and four, the fixed effect estimates show that the fintech variable is consistently negative and significant in both models with four different proxies of fintech. The interaction variable between fintech and big bank dummy is positive in both models with all proxies of fintech, although only significant when fintech is represented by the growth of transactions (both lending and borrowing). The coefficient value of the interaction variable between fintech and big bank dummy is also always larger than the interaction variable between fintech and medium bank dummy. The interaction variable between fintech and medium bank dummy itself is not significant in all fixed effect estimates of models three 
and four. These findings suggest that small and medium banks tend to be similarly negatively affected by fintech, while big banks are less negatively affected by the growth of fintech. The estimations of model one and two yields similar results.

The fixed effect estimates of model five show that the fintech variable is positive and significant, except when fintech is represented by lender account growth. Both interaction variables of fintech and bank dummy show no statistical significance. However, when these two variables are compared, the coefficients of the interaction variable with the big bank dummy are higher than the one with the medium bank dummy. The interaction variable between fintech and the COVID-19 dummy only shows statistical significance for the regressions in which fintech is proxied by lender account growth. When other proxies of fintech are used, the interaction variable between fintech and the COVID-19 dummy shows no statistical significance and mixed coefficient signs. For the interaction variables of fintech, bank dummy, and the COVID-19 pandemic, only the variables in the estimations whereby fintech is proxied by borrowing transaction growth return statistically significant results.

The GMM results show us that the fintech variable tends to be negative. Of the twelve estimates using models three to five and the four proxies of fintech, ten of those estimations yield a negative fintech coefficient, with four being statistically significant. On the other hand, the coefficients of all other fintech-related variables in almost all GMM estimates show statistical insignificance and mixed signs. These findings suggest that fintech tends to impact banks negatively no matter the size of the bank.

All in all, the fixed effect and GMM estimates show us that fintech negatively affects bank stock returns. The severity of the negative impact is less for the bigger banks, as indicated by the fixed effect estimates. However, when the pandemic is taken into account, fintech seems to affect bank stock returns positively. These findings suggest we conduct further analysis on the changes in the relationship between fintech and banks during the COVID-19 pandemic.

We conduct further analysis on the changes in the relationship between fintech and banks during the COVID-19 pandemic by estimating model four using halfyearly data for each semester from the second semester of 2018 to the second semester of 2020 (a total of five different time horizons). The estimation is conducted using the two-step system GMM estimator. We then obtain the values of $\delta_{1}$ to $\delta_{3}$ (parameters of FINTECH, BIG_FINTECH, and MED_FINTECH, respectively) and compare them in a graphical format.

The graphs built based on the values of $\delta_{1}$ to $\delta_{3}$ are presented in Figure 2. Figure 2 tells us that when estimated using the COVID-19 pandemic period data only, fintech tends to have a more positive impact on big banks (as indicated by $\delta_{2}$ ), while its impact on medium and small banks are considerably more negative (as indicated by $\delta_{1}$ and $\delta_{3}$ ). These findings are consistent across the four proxies of fintech. These findings help us to explain why after controlling for the pandemic in model five, fintech has a positive impact on banks in the fixed effect estimation. 


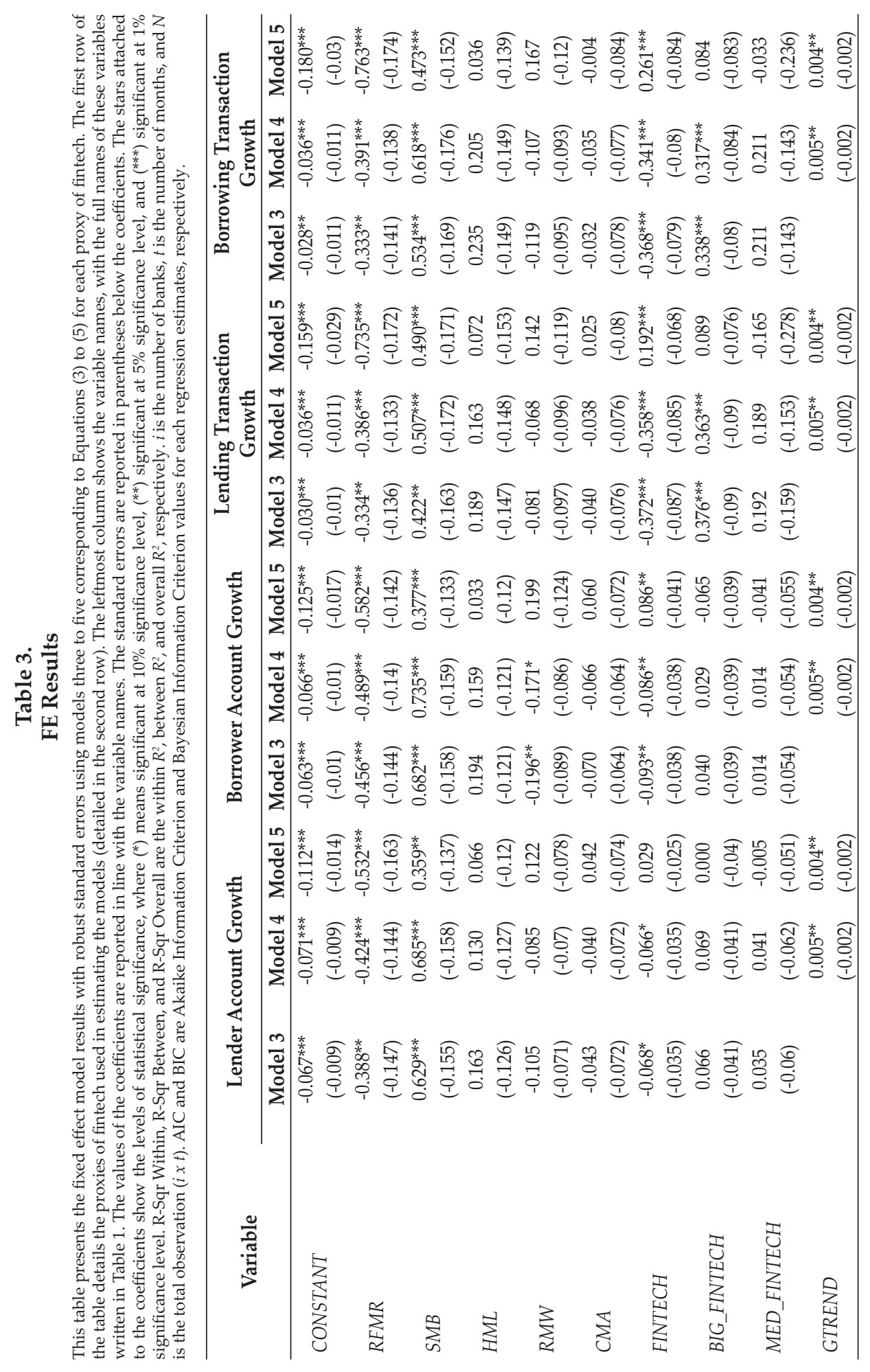




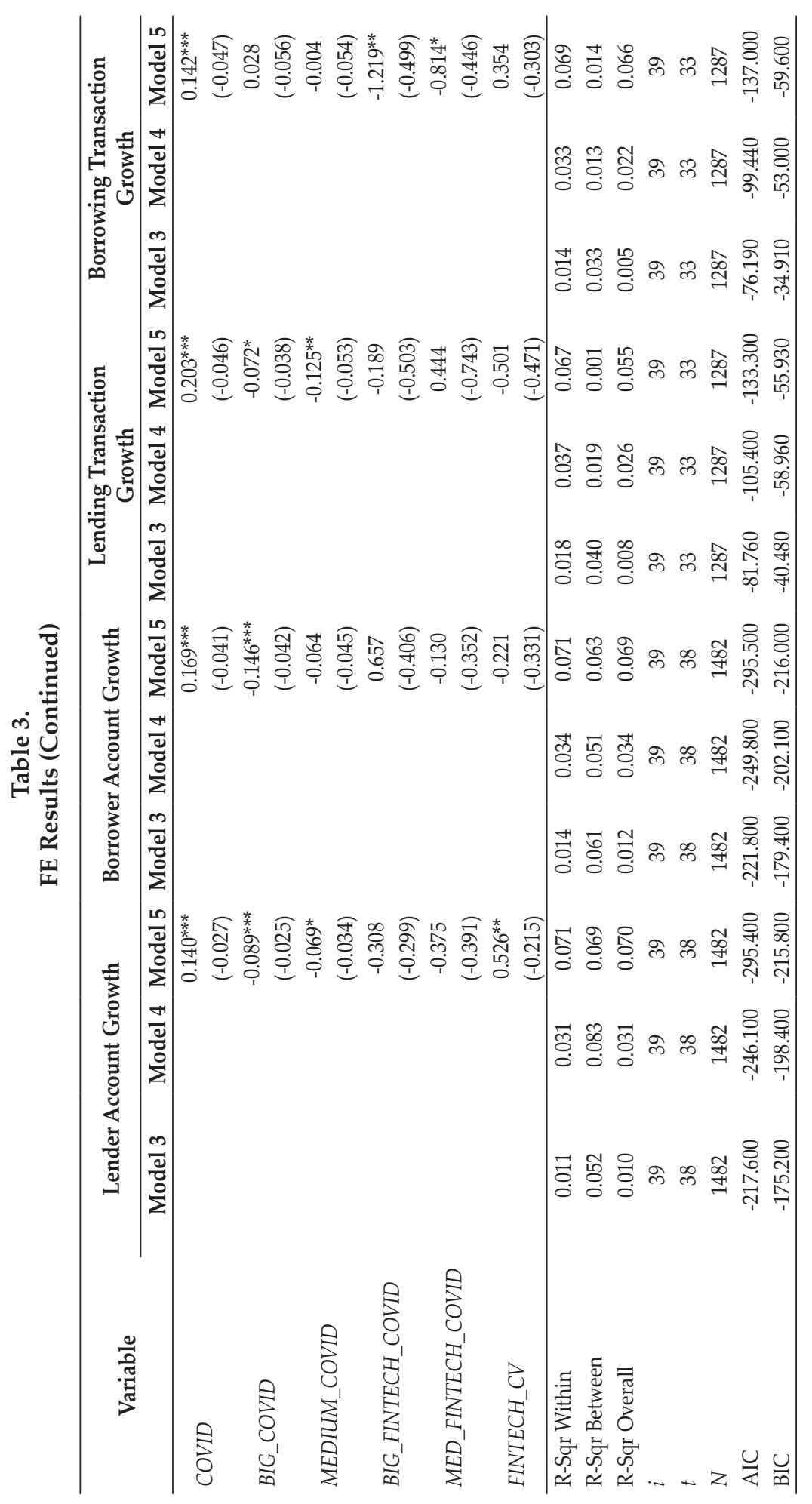




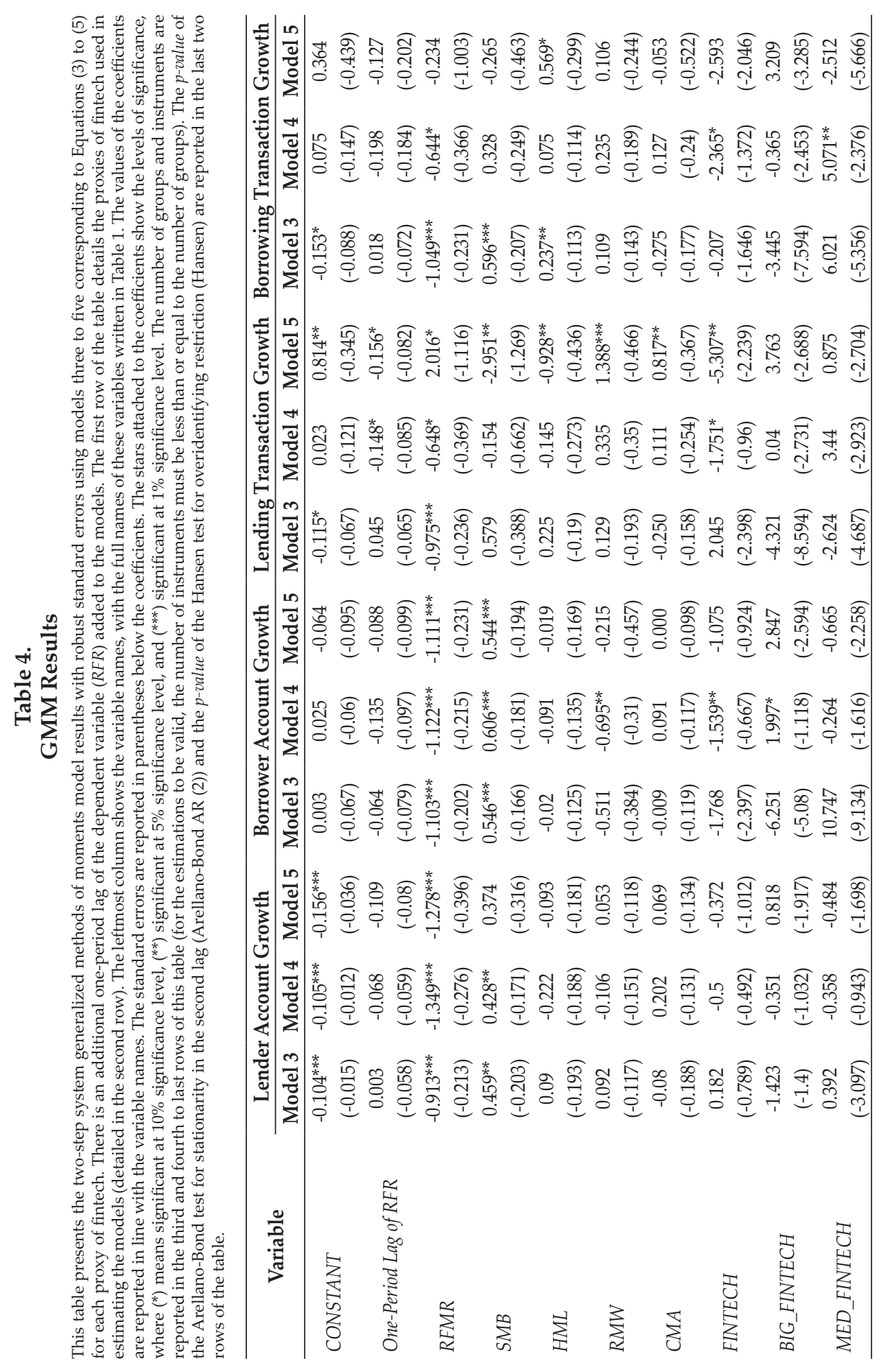




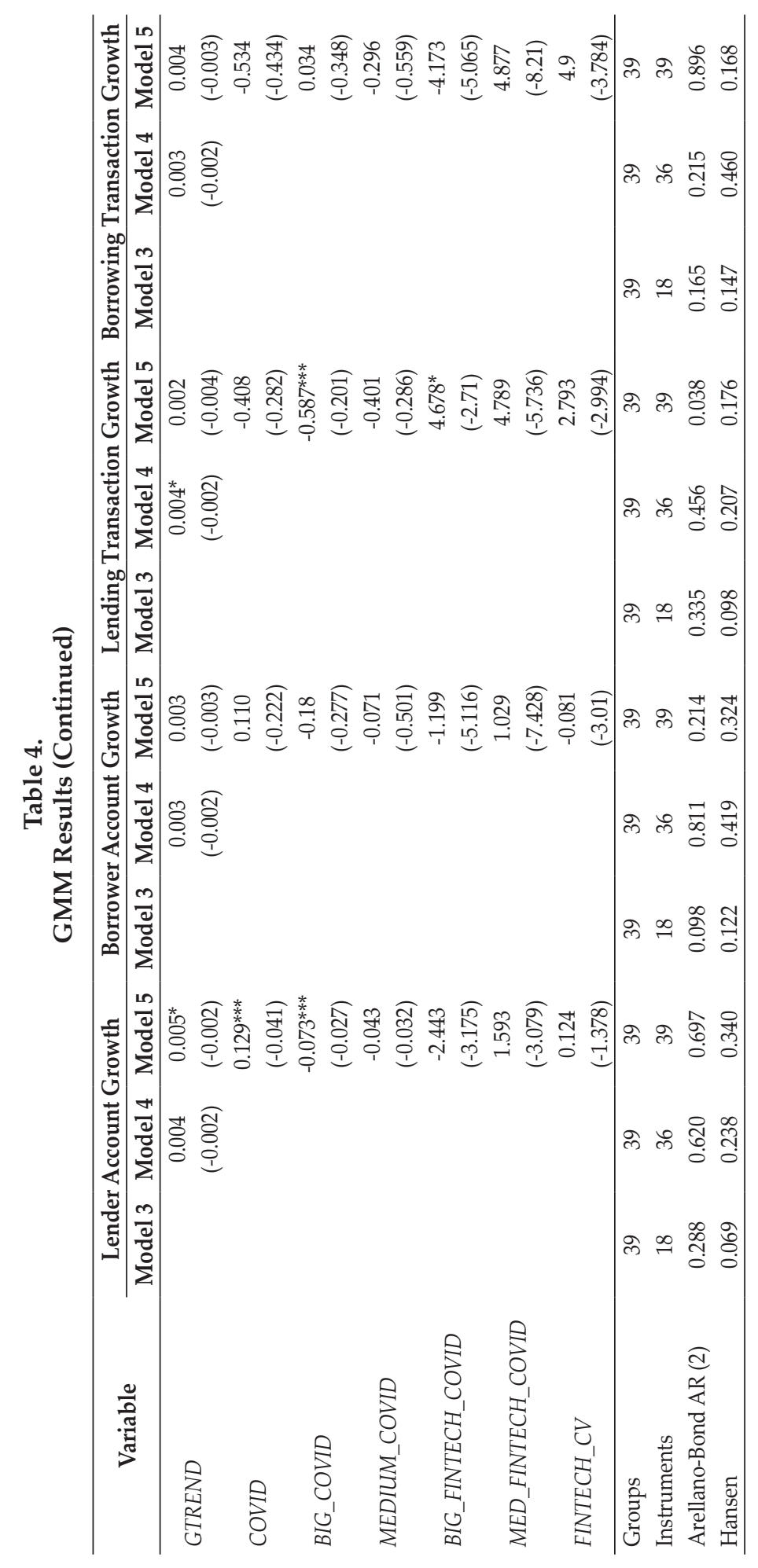


Figure 2.

\section{Changes in the Relationship Between Fintech and Banks}

This figure displays the changes in the relationship between fintech and banks as shown by the value of parameters $\delta_{1}$ to $\delta_{3}$ from Equation (4). The values of these parameters are obtained through the two-step system GMM estimation of Equation (4) using half-yearly data from the second half of 2018 to the second half of 2020. There are four panels in this figure (a to d), with each panel having its own unique proxy of fintech.

(a) Fintech = Lender Account Growth

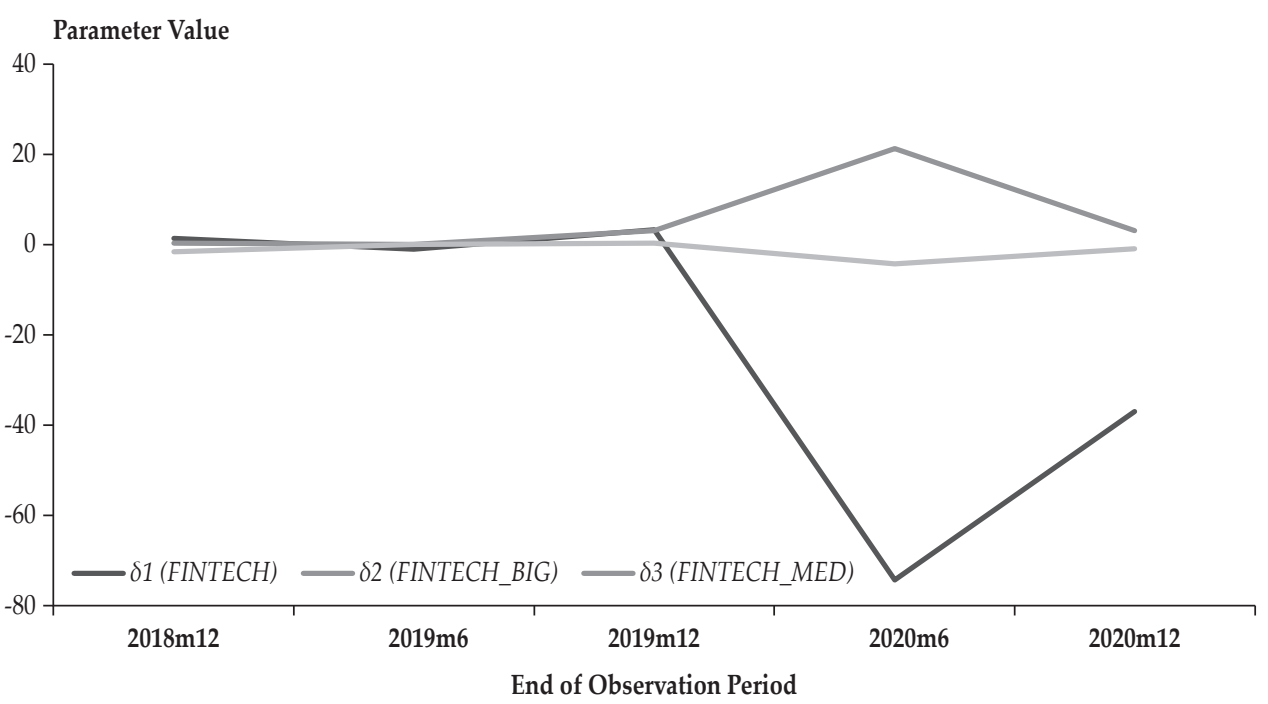

(b) Fintech $=$ Borrower Account Growth

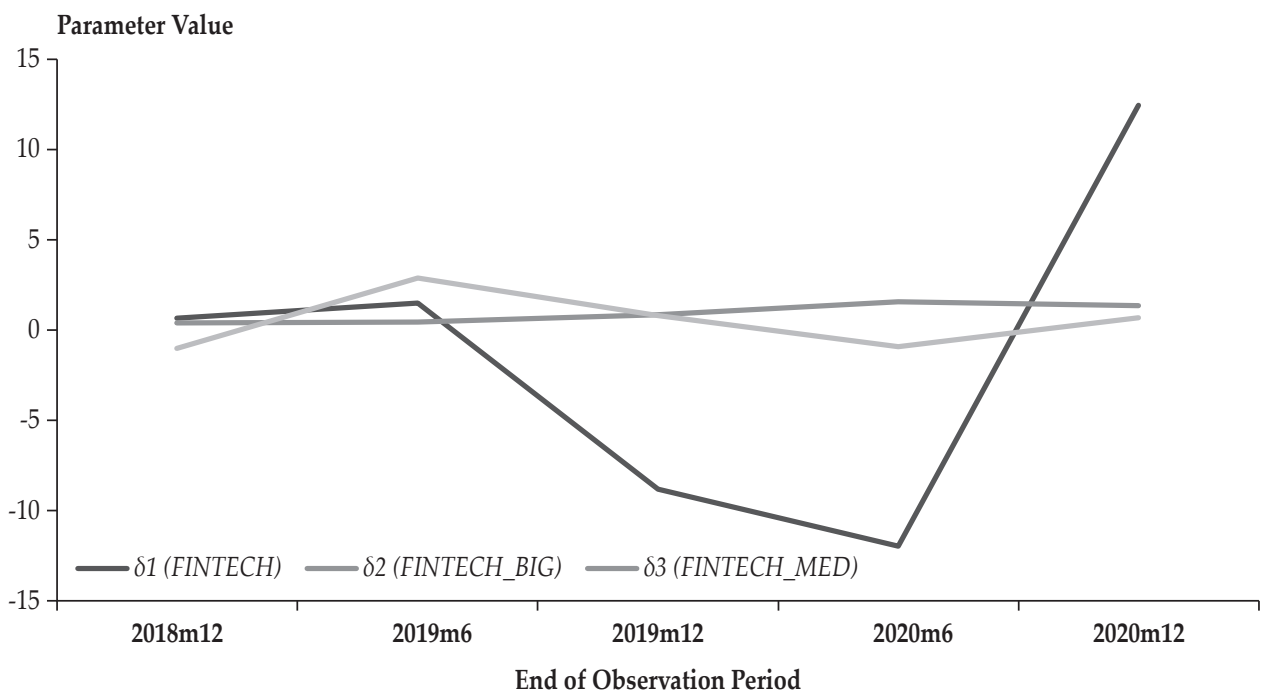


Figure 2.

Changes in the Relationship Between Fintech and Banks (Continued)

(c) Fintech $=$ Lending Transaction Growth

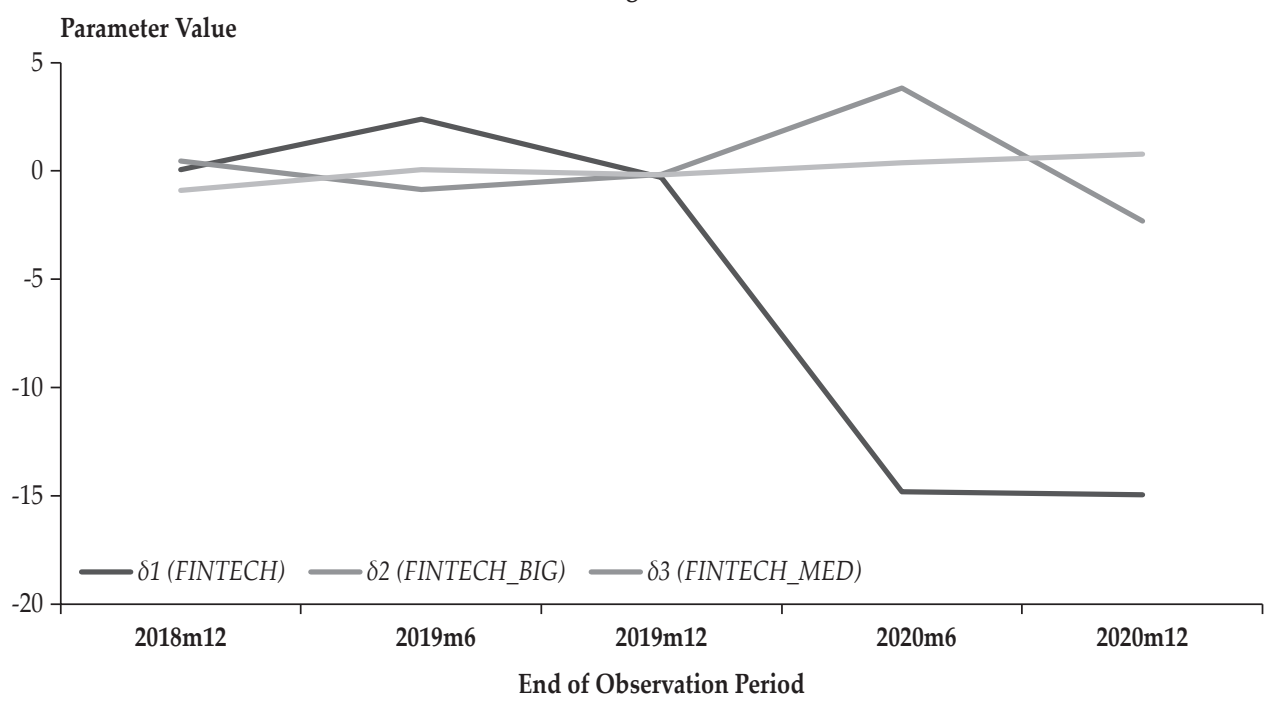

(d) Fintech $=$ Borrowing Transaction Growth

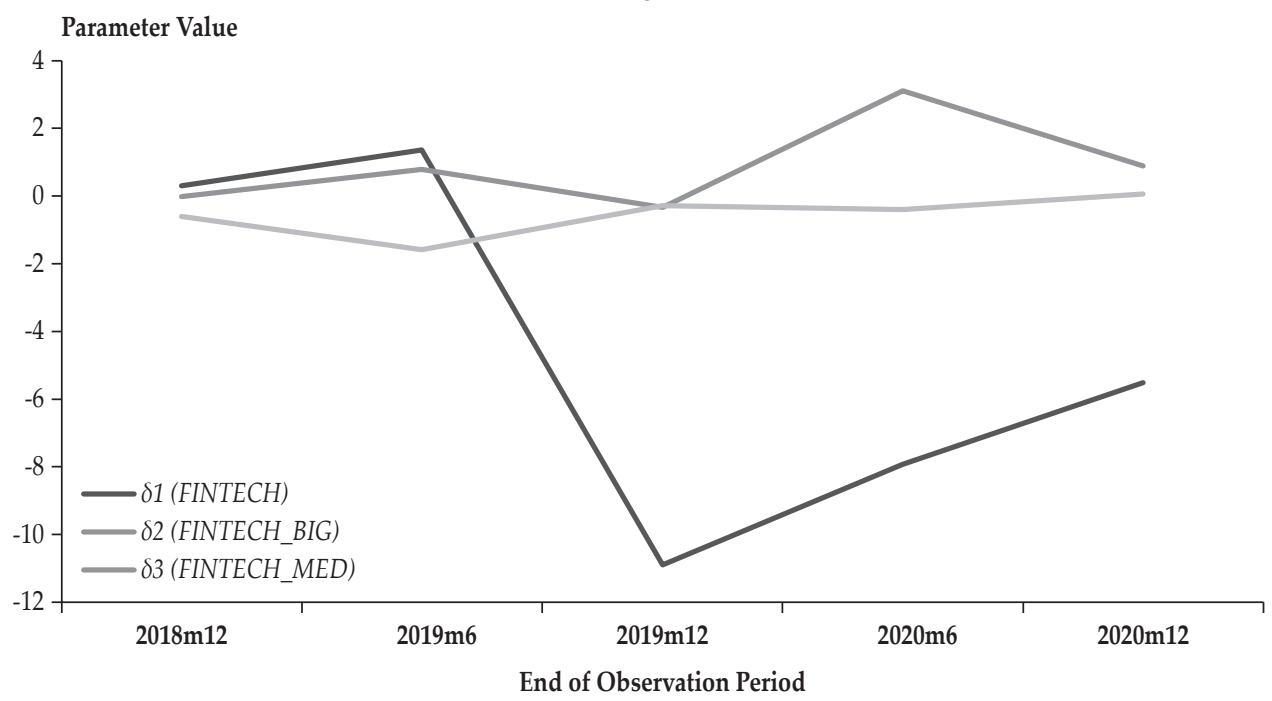

The changes in the relationship between fintech and banks during the pandemic also suggest an exemplification of the relatively more positive (or less negative) impact of fintech on bigger banks and the opposite for smaller banks. These findings support the argument that bigger banks tend to benefit from the emergence of fintech. Bigger banks have more resources to adopt the technological spillover from fintech innovations. With these resources, they can also build 
partnerships with or even incorporate fintech companies into their business (Cole et al., 2019; Lee et al., 2021; Li et al., 2017). The pandemic has further boosted fintech growth and, on the other hand, made banks that are not ready with a fintech-like business model to be left behind (the smaller banks) (Fu and Mishra, 2020; Najaf et al., 2021; Wu and Olson, 2020).

With these findings in mind, we believe it is essential to discuss its implications to the financial system, especially on the regulatory strategies adopted by the financial authorities. The following sub-section will focus on the implication of these findings for the open banking strategies adopted by the Indonesian financial authorities and for the future of the Indonesian financial system in general.

\section{Implications for the Financial System}

The empirical findings of this study have an important implication for the future of the Indonesian financial system. This implication must be considered in relation to current fintech development and future policy directions of financial authorities in Indonesia.

The fintech industry in Indonesia shows a significant surge in early 2016. Fintech firms emphasize the utilization of technology in their business model. In its early stage, fintech companies, both domestic and foreign, competed to obtain licenses from the authorities to operate. Fintech companies in Indonesia perform their business in a more efficient way relative to their bank counterparts. This emergence of fintech poses both threats and opportunities to the Indonesian financial system (Sjamsudin, 2019). Sjamsudin (2019) also states that the development of fintech has been highly supported by financial authorities in Indonesia. The support by authorities is meant to improve financial inclusion in Indonesia. As pointed out by Davis et al. (2017), the risks and opportunities posed by fintech are more significant in Indonesia relative to more developed countries. Financial inclusion, especially for small and medium-sized enterprises, which play a great role in the Indonesian economy, remains low while the technological capacity is high (Davis et al., 2017).

Besides financial inclusion, several other benefits have also emerged because of fintech innovation. As noted by Jameaba (2020), the development of fintech in Indonesia has enabled the existing financial institutions to develop a new business model that benefits from "data collection, storage, sharing, and discerning actionable insights." This new business model is called "open banking." Open banking refers to the kind of business model that "allows non-banks and Fintech to find their spot in the Financial Services industry" (PWC, 2020). Open banking business model centers around the usage of open application programming interfaces, which enable third-party developers (fintech and non-fintech companies) to build applications and services around the financial institution (like banks) (PWC, 2020). This business model is the one that is proposed by financial authorities in Indonesia to digitally transform the banking industry (Bank Indonesia, 2019; Batunanggar, 2019); the open banking business model, in simple terms, refers to the business model that focuses on creating cooperation between banks and the new entrants in the financial industry and other tech-centric start-ups. Moreover, Jameaba (2020) also points out that the development of fintech has promoted inclusive growth 
in Indonesia. Looking through all of these benefits and possible cooperation with existing financial institutions, it is then evident for financial authorities in Indonesia to promote the growth of fintech and digitally transform the incumbent banks by adopting the open banking business model strategy.

The promotion of the open banking business model to digitally transform the incumbent banks and develop fintech as part of the financial ecosystem is what financial authorities in Indonesia have planned. Bank Indonesia (2019), in its blueprint for Indonesia Payment System 2025 promotes the interlink between fintech and banks as one of its five visions. The other four are "the integration of digital economy and finance, digital transformation of the banking industry, risk and competition management, and managing national interest on crossborder use of finance and digital technology" (Bank Indonesia, 2019). In short, Bank Indonesia aims at a sound financial and economic ecosystem with the incorporation of open banking business models for banks, fintech companies, and the digital economy. This vision is also shared by the Financial Service Authority (OJK). As stated in a policy brief by Batunanggar (2019), OJK aims at "developing a holistic fintech road map in line with a national digital economy strategy and road map aimed at developing a sound ecosystem, including data protection, customer protection, regulation and supervision, regulatory sandbox, innovation hub, risk management, and cyber-risk." To support his aim, OJK points out the vitality of collaboration between fintech and the existing financial institutions. In short, OJK wants to promote the collaboration between fintech and the incumbent financial institutions (like banks) to realize an "inclusive and sustainable financial ecosystem" which incorporates fintech and the digital economy. These strategies and policies adopted by Bank Indonesia and OJK have been said to be "pragmatic" and "close to best practice" (Davis et al., 2017). Financial authorities in Indonesia have moved quickly in facing the emergence of fintech in the financial ecosystem (Davis et al., 2017).

The findings of this study have an important implication for the strategies adopted by financial authorities in Indonesia. This study found that the growth of fintech has a different impact on larger banks and smaller banks. The impact on larger banks is less negative compared to smaller banks. This implies that the implementation of the open banking business model will be harder to achieve by smaller banks than by larger banks (which already benefited from the growth of fintech). It is, thus, important for the financial authorities to give more attention to smaller banks in the implementation of the financial authorities' strategies to achieve a sound financial and economic ecosystem through the incorporation of fintech and the digital economy.

\section{CONCLUDING REMARKS}

This study investigates the relationship between fintech and banks and how this relationship is affected by the COVID-19 pandemic. We use monthly stock data of all banks consistently listed in the Indonesian Stock Exchange from February 2018 to March 2021. The banks are classified into three categories based on the sizes of their core capital. For fintech data, we use a total of four proxies that encompass both lending and borrowing aspects of peer-to-peer lending fintech. 
The data are sourced from the Financial Service Authority Fintech database, Yahoo Finance, and Google. To provide robust results, we use five model specifications. Furthermore, we also estimate the models using both the fixed effect and the twostep system generalized method of moments estimators. To see the dynamics of the relationship between fintech and banks before and during the pandemic, we estimate one of our five models using half-yearly data for each semester from the second semester of 2018 to the second semester of 2020.

The fixed effect and the two-step system generalized method of moments estimates show that fintech tends to negatively affect banks' stock returns, although the effect is not statistically significant in all models. The severity of the negative impact is less for the bigger banks, as indicated by the fixed effect estimates. Furthermore, the analysis of the changes in the relationship between fintech and bank before and during the pandemic tells us that, when estimated using data for the COVID-19 pandemic period only, fintech tends to have a more positive impact on big banks, while the impact on medium and small banks are considerably more negative. These findings are consistent across the four proxies of fintech. These findings help us to explain why, after controlling for the pandemic, the positive impact of fintech tends to be statistically significant. The changes in the relationship between fintech and banks during the pandemic also suggest an exemplification of the relatively more positive (or less negative) impact of fintech on bigger banks and the opposite for smaller banks. These findings support the argument that bigger banks tend to benefit more from the emergence of fintech. We believe that these findings have significant implications for the Indonesian financial authorities' open banking strategy and for the future of the Indonesian financial system in general.

This study is still limited in some ways. We have not considered the reverse causality of the impact of banks on fintech. The COVID-19 pandemic has demonstrated how a significant decline in the banking industry's performance can spike the public's interest in fintech. Moreover, our study on the changes in the relationship between fintech and banks during the pandemic is also limited since we have not develop more sophisticated tools and acquire more data to provide more robust and detailed results and analysis. We believe these issues are the significant and interesting ones for future research.

\section{ACKNOWLEDGMENTS}

This research received funding from Bank Indonesia through Bantuan Penelitan Bank Indonesia program. We would also like to thank Dr. Bernard Njindan Iyke and Prof. Aun Rizvi from Asia-Pacific Applied Economics Association for their suggestions that have helped improve the quality of this paper. 


\section{REFERENCES}

Anagnostopoulos, I. (2018). Fintech and Regtech: Impact on Regulators and Banks. Journal of Economics and Business, 100, 7-25. https://doi.org/10.1016/j.jeconbus.2018.07.003

Arner, D. W., Barberis, J. N., \& Buckley, R. P. (2015). The Evolution of Fintech: A New Post-Crisis Paradigm? SSRN Electronic Journal, January. https://doi.org/10.2139/ssrn.2676553

Bank Indonesia. (2019). Navigating the National Payment Systems in Digital Era.

Batunanggar, S. (2019). Fintech Development and Regulatory Framworks in Indonesia (Issue ADBI Working Paper1014). https://www.adb.org/publications/fintechdevelopment-regulatory-frameworks-indonesia

Bordalo, P., Gennaioli, N., La Porta, R., \& Shleifer, A. (2020). Expectations of Fundamentals and Stock Market Puzzles. https://doi.org/10.3386/w27283

Buchak, G., Matvos, G., Piskorski, T., \& Seru, A. (2018). Fintech, Regulatory Arbitrage, and the Rise of Shadow Banks. Journal of Financial Economics, 130, 453-483. https://doi.org/10.1016/j.jfineco.2018.03.011

Cole, R. A., Cumming, D. J., \& Taylor, J. (2019). Does FinTech Compete with or Complement Bank Finance? SSRN Electronic Journal. https://doi.org/10.2139/ssrn.3302975

Davis, K., Maddock, R., \& Foo, M. (2017). Catching Up with Indonesia's Fintech Industry. Law and Financial Markets Review, 11, 33-40. https://doi.org/10.1080/17521440.2017.1336398

Demirguc-kunt, A., Pedraza, A., \& Ortega, C. R. (2020). Banking Sector Performance During the COVID-19 Crisis (No. 9363; Issue August). https://doi.org/https://dx.doi.org/10.2139/ssrn.3689789

Dewi, D. R., \& Suartana, W. (2018). Komparasi Capital Asset Pricing Model dan Fama-French Three Factor Model dalam Memprediksi Return Saham. E-Journal Ekonomi dan Bisnis Universitas Udayana, 3, 747-774.

Dorfleitner, G., Hornuf, L., Schmitt, M., \& Weber, M. (2017). Definition of FinTech and Description of the FinTech Industry. FinTech in Germany, 1-121. https://doi.org/10.1007/978-3-319-54666-7

Fama, E. F., \& French, K. R. (1999). A Five-factor Asset Pricing Model. Journal of Financial Economics. https://doi.org/10.1016/j.jfineco.2014.10.010

Fama, E. F., \& French, K. R. (2005). The Return on Investment and the Cost of Capital. The Journal of Finance, 54.

Fu, J., \& Mishra, M. (2020). Fintech in the Time of COVID-19: Trust and Technological Adoption Furing Crises. Swiss Finance Institute Research Paper Series, December, 1-56. https://ssrn.com/abstract=3588453

Heaton, J., \& Lucas, D. (1999). Stock Prices and Fundamentals. NBER Macroeconomics Annual, 14, 213-242. https://doi.org/10.1086/654387

Ho, L.-M., Schafferer, C., Lee, J.-M., Yeh, C.-Y., \& Hsieh, C.-J. (2018). Raising Cigarette Excise Tax to Reduce Consumption in Low-and Middle-income Countries of the Asia-Pacific Region: A Simulation of the Anticipated Health and Taxation Revenues Impacts. BMC Public Health, 18, 1-9. https://doi.org/10.1186/s12889-018-6096-z 
Hornuf, L., \& Haddad, C. (2018). The Emergence of the Global Fintech Market: Economic and Technological Determinants Christian Haddad The Emergence of the Global Fintech Market: Economic and Technological Determinants Abstract. Small Business Economics, 81-105.

Jagtiani, J., \& Lemieux, C. (2018). Do Fintech Lenders Penetrate Areas that are Underserved by Traditional Banks? Journal of Economics and Business, 100, 4354. https://doi.org/10.1016/j.jeconbus.2018.03.001

Jameaba, M. (2020). Digitization, FinTech Disruption, and Financial Stability: The Case of the Indonesian Banking Sector. SSRN Electronic Journal, 01, 1-49. https://doi.org/10.2139/ssrn.3529924

Johnson, M. W., \& Christensen, C. M. (2000). Reinventing You Business Model. Harvard Business Review, 16, 14-21.

Lee, C.-C., Li, X., Yu, C.-H., \& Zhao, J. (2021). Does Fintech Innovation Improve Bank Efficiency? Evidence from China's Banking Industry. International Review of Economics E Finance, 74, 468-483. https://doi.org/10.1016/j.iref.2021.03.009

Lee, I., \& Shin, Y. J. (2018). Fintech: Ecosystem, Business Models, Investment Decisions, and Challenges. Business Horizons, 61, 35-46. https://doi.org/10.1016/j.bushor.2017.09.003

Li, Y., Spigt, R., \& Swinkels, L. (2017). The impact of FinTech Startups on Incumbent Retail Banks' Share Prices. Financial Innovation, 3. https://doi.org/10.1186/s40854-017-0076-7

Mirzaei, A., Saad, M., \& Emrouznejad, A. (2020). Bank Stock Performance During the COVID-19 Crisis: Does Efficiency Explain Why Islamic Banks Fared Relatively Better? SSRN Electronic Journal. https://doi.org/10.2139/ssrn.3702116

Najaf, K., Subramaniam, R. K., \& Atayah, O. F. (2021). Understanding the Implications of FinTech Peer-to-Peer (P2P) Lending during the COVID-19 Pandemic. Journal of Sustainable Finance $\mathcal{E}$ Investment, 1-16. https://doi.org/10.1080/20430795.2021.1917225

Nguyen, C. P., Schinckus, C., \& Hong Nguyen, T. V. (2019). Google Search and Stock Returns in Emerging Markets. Borsa Istanbul Review, 19, 288-296. https://doi.org/10.1016/j.bir.2019.07.001

Nuryakin, C., Aisha, L., Waraney, N., \& Massie, G. (2019). Financial Technology in Indonesia : A Fragmented Instrument for Financial Inclusion ? LPEM-FEB UIWorking Paper 036, May, 1-9.

Olivia, S., Gibson, J., \& Nasrudin, R. (2020). Indonesia in the Time of Covid-19. Bulletin of Indonesian Economic Studies, 56, 143-174. https://doi.org/10.1080/00074918.2020.1798581

Patwardhan, A. (2018). Peer-To-Peer Lending. In Handbook of Blockchain, Digital Finance, and Inclusion, Volume 1: Cryptocurrency, FinTech, InsurTech, and Regulation (1st ed., Vol. 1). Elsevier Inc. https://doi.org/10.1016/B978-0-12810441-5.00018-X

Phan, D. H. B., Narayan, P. K., Rahman, R. E., \& Hutabarat, A. R. (2019). Do Financial Technology Firms Influence Bank Performance? Pacific Basin Finance Journal, 101210. https://doi.org/10.1016/j.pacfin.2019.101210

PWC. (2018). Digital Banking in Indonesia 2018. PwC Survey, July, 1-48. https:// www.pwc.com/id/en/publications/assets/financialservices/digital-bankingsurvey-2018-pwcid.pdf 
PWC. (2020). Still Trying to Figure Out Open Banking? You are Certainly Not Alone.

Salisu, A. A., Ogbonna, A. E., \& Adediran, I. (2021). Stock-induced Google Trends and the Predictability of Sectoral Stock Returns. Journal of Forecasting, 40, 327345. https://doi.org/10.1002/for.2722

Siek, M., \& Sutanto, A. (2019). Impact Analysis of Fintech on Banking Industry. Proceedings of 2019 International Conference on Information Management and Technology, ICIMTech 2019, 1 (August), 356-361. https://doi.org/10.1109/ICIMTech.2019.8843778

Sjamsudin, S. H. (2019). The Impact of the Development of Fintech on The Existing Financial Services in Indonesia. International Journal of Advanced Research in Technology and Innovation, 1, 14-23. https://blog.iese.edu/xvives/files/2018/02/EE_2.2017.pdf

Treynor, J. L. (1961). Market Value, Time, and Risk. SSRN Electronic Journal. https://doi.org/10.2139/ssrn.2600356

Wu, D. D., \& Olson, D. L. (2020). The Effect of COVID-19 on the Banking Sector. In Pandemic Risk Management in Operations and Finance (pp. 89-99). https://doi.org/10.1007/978-3-030-52197-4_8 


\section{APPENDIX}

\section{Table A.1. \\ Sampled Banks}

This table shows all the banks used in this study. Ticker is the four-letter stock code for banks on the Indonesia Stock Exchanges. Company Name is the full name of the banks, and Classification shows the bank classification based on the sizes of their core capital.

\begin{tabular}{|c|c|c|}
\hline Ticker & Company Name & Classification \\
\hline AGRO & PT Bank Rakyat Indonesia Agroniaga Tbk & Small \\
\hline AGRS & PT Bank IBK Indonesia Tbk & Small \\
\hline ARTO & PT Bank Jago Tbk & Medium \\
\hline ВАВР & PT Bank MNC Internasional Tbk & Small \\
\hline BACA & PT Bank Capital Indonesia Tbk & Small \\
\hline BBCA & PT Bank Central Asia Tbk & Big \\
\hline BBHI & PT Bank Harda Internasional Tbk & Small \\
\hline BBKP & PT Bank KB Bukopin Tbk & Medium \\
\hline BBMD & PT Bank Mestika Dharma Tbk & Small \\
\hline BBNI & PT Bank Negara Indonesia (Persero) Tbk & Big \\
\hline BBRI & PT Bank Rakyat Indonesia (Persero) Tbk & Big \\
\hline BBTN & PT Bank Tabungan Negara (Persero) Tbk & Medium \\
\hline BВYВ & PT Bank Neo Commerce Tbk & Small \\
\hline BDMN & PT Bank Danamon Indonesia Tbk & Big \\
\hline BEKS & PT. Bank Pembangunan Daerah Banten & Small \\
\hline BGTG & PT Bank Ganesha Tbk & Small \\
\hline BINA & PT Bank Ina Perdana Tbk & Small \\
\hline BJBR & PT Bank Pembangunan Daerah Jawa Barat dan Banten Tbk & Medium \\
\hline BJTM & PT Bank Pembangunan Daerah Jawa Timur Tbk & Medium \\
\hline BKSW & PT Bank QNB Indonesia Tbk & Small \\
\hline BMAS & PT Bank Maspion Indonesia Tbk & Small \\
\hline BMRI & PT Bank Mandiri (Persero) Tbk & Big \\
\hline BNBA & P.T. Bank Bumi Arta Tbk & Small \\
\hline BNGA & PT Bank CIMB Niaga Tbk & Big \\
\hline BNII & PT Bank Maybank Indonesia Tbk & Medium \\
\hline BNLI & PT Bank Permata Tbk & Big \\
\hline BSIM & PT Bank Sinarmas Tbk & Medium \\
\hline BTPN & PT Bank BTPN Tbk & Big \\
\hline BVIC & PT Bank Victoria International Tbk & Small \\
\hline DNAR & PT Bank Oke Indonesia Tbk & Small \\
\hline INPC & PT Bank Artha Graha Internasional Tbk & Small \\
\hline MAYA & PT Bank Mayapada Internasional Tbk & Medium \\
\hline MCOR & PT Bank China Construction Bank Indonesia Tbk & Medium \\
\hline MEGA & PT Bank Mega Tbk & Medium \\
\hline NISP & PT Bank OCBC NISP Tbk & Big \\
\hline NOBU & PT Bank Nationalnobu Tbk & Small \\
\hline PNBN & P.T. Bank Pan Indonesia Tbk & Big \\
\hline PNBS & PT Bank Panin Dubai Syariah Tbk & Small \\
\hline SDRA & PT Bank Woori Saudara Indonesia 1906 Tbk & Medium \\
\hline
\end{tabular}


Table A.2.

\section{FE Results for Models One and Model Two}

This table presents the fixed effect model results with robust standard errors using models one and two, corresponding to Equations (1) and (2) for each proxy of fintech. The first row of the table details the proxies of fintech used in estimating the models (detailed in the second row). The leftmost column shows the variable names, with the full names of these variables written in Table 1 . The values of the coefficients are reported in line with the variable names. The standard errors are reported in parentheses below the coefficients. The stars attached to the coefficients show the levels of significance, where $\left(^{*}\right)$ means significant at $10 \%$ significance level, $\left({ }^{* *}\right)$ significant at $5 \%$ significance level, and $\left.{ }^{* * *}\right)$ significant at $1 \%$ significance level. R-Sqr Within, R-Sqr Between, and R-Sqr Overall are the within $R^{2}$, between $R^{2}$, and overall $R^{2}$, respectively. $i$ is the number of banks, $t$ is the number of months, and $N$ is the total observation $(i x t)$. AIC and BIC are Akaike Information Criterion and Bayesian Information Criterion values for each regression estimates, respectively.

\begin{tabular}{|c|c|c|c|c|c|c|c|c|}
\hline \multirow[t]{2}{*}{ Variable } & \multicolumn{2}{|c|}{$\begin{array}{l}\text { Lender Account } \\
\text { Growth }\end{array}$} & \multicolumn{2}{|c|}{$\begin{array}{c}\text { Borrower Account } \\
\text { Growth }\end{array}$} & \multicolumn{2}{|c|}{$\begin{array}{l}\text { Lending } \\
\text { Transaction } \\
\text { Growth }\end{array}$} & \multicolumn{2}{|c|}{$\begin{array}{c}\text { Borrowing } \\
\text { Transaction } \\
\text { Growth }\end{array}$} \\
\hline & Model 1 & Model 2 & Model 1 & Model 2 & Model 1 & Model 2 & Model 1 & Model 2 \\
\hline \multirow[t]{2}{*}{ CONSTANT } & $-0.044^{* * *}$ & $-0.059^{* * *}$ & $-0.037^{* * *}$ & $-0.052^{* * *}$ & -0.009 & $-0.025^{* * *}$ & -0.004 & $-0.020^{* *}$ \\
\hline & $(-0.005)$ & $(-0.008)$ & $(-0.006)$ & $(-0.007)$ & $(-0.007)$ & $(-0.008)$ & $(-0.008)$ & $(-0.009)$ \\
\hline \multirow[t]{2}{*}{$R F M R$} & -0.023 & $-0.276^{* *}$ & -0.033 & $-0.281^{* *}$ & -0.103 & $-0.246^{*}$ & -0.034 & $-0.236^{*}$ \\
\hline & $(-0.083)$ & $(-0.134)$ & $(-0.078)$ & $(-0.123)$ & $(-0.089)$ & $(-0.131)$ & $(-0.078)$ & $(-0.13)$ \\
\hline \multirow[t]{2}{*}{$S M B$} & & $0.579^{* * *}$ & & $0.575^{* * *}$ & & $0.392^{* * *}$ & & $0.502^{* * *}$ \\
\hline & & $(-0.132)$ & & $(-0.129)$ & & $(-0.136)$ & & $(-0.149)$ \\
\hline \multirow[t]{2}{*}{$H M L$} & & 0.181 & & 0.153 & & 0.199 & & 0.248 \\
\hline & & $(-0.112)$ & & $(-0.115)$ & & $(-0.146)$ & & $(-0.15)$ \\
\hline \multirow[t]{2}{*}{ FINTECH } & $-0.059^{*}$ & $-0.075^{* *}$ & $-0.070^{* *}$ & $-0.077^{* *}$ & $-0.402^{* * *}$ & $-0.368^{* * *}$ & $-0.378^{* * *}$ & $-0.375^{* * *}$ \\
\hline & $(-0.029)$ & $(-0.033)$ & $(-0.033)$ & $(-0.034)$ & $(-0.086)$ & $(-0.084)$ & $(-0.071)$ & $(-0.075)$ \\
\hline \multirow[t]{2}{*}{ BIG_FINTECH } & 0.066 & 0.066 & 0.040 & 0.040 & $0.376^{* * *}$ & $0.376^{* * *}$ & $0.338^{* * *}$ & $0.338^{* * *}$ \\
\hline & $(-0.041)$ & $(-0.041)$ & $(-0.039)$ & $(-0.039)$ & $(-0.09)$ & $(-0.09)$ & $(-0.08)$ & $(-0.08)$ \\
\hline \multirow[t]{2}{*}{ MED_FINTECH } & 0.035 & 0.035 & 0.014 & 0.014 & 0.192 & 0.192 & 0.211 & 0.211 \\
\hline & $(-0.06)$ & $(-0.06)$ & $(-0.054)$ & $(-0.054)$ & $(-0.159)$ & $(-0.159)$ & $(-0.143)$ & $(-0.143)$ \\
\hline R-Sqr Within & 0.001 & 0.013 & 0.002 & 0.015 & 0.015 & 0.019 & 0.008 & 0.015 \\
\hline R-Sqr Between & 0.052 & 0.052 & 0.061 & 0.061 & 0.040 & 0.040 & 0.033 & 0.033 \\
\hline R-Sqr Overall & 0.000 & 0.012 & 0.001 & 0.014 & 0.005 & 0.008 & 0.001 & 0.006 \\
\hline$i$ & 39 & 39 & 39 & 39 & 39 & 39 & 39 & 39 \\
\hline$t$ & 38 & 38 & 38 & 38 & 33 & 33 & 33 & 33 \\
\hline$N$ & 1482 & 1482 & 1482 & 1482 & 1287 & 1287 & 1287 & 1287 \\
\hline AIC & -209.900 & -224.700 & -212.500 & -227.500 & -85.420 & -86.790 & -77.070 & -82.200 \\
\hline BIC & -188.700 & -192.900 & -191.300 & -195.700 & -64.780 & -55.830 & -56.430 & -51.240 \\
\hline
\end{tabular}


Table A 3.

\section{GMM Results for Models One and Model Two}

This table presents the two-step system generalized methods of moments model results with robust standard errors using models one and two, corresponding to Equations (1) and (2) for each proxy of fintech. There is an additional one-period lag of the dependent variable (RFR) added to the models. The first row of the table details the proxies of fintech used in estimating the models (detailed in the second row). The leftmost column shows the variable names, with the full names of these variables written in Table 1 . The values of the coefficients are reported in line with the variable names. The standard errors are reported in parentheses below the coefficients. The stars attached to the coefficients show the levels of significance, where $\left(^{*}\right)$ means significant at $10 \%$ significance level, $\left(^{* *}\right)$ significant at $5 \%$ significance level, and $\left(^{* * *}\right)$ significant at $1 \%$ significance level. The number of groups and instruments are reported in the third and fourth to last rows of this table (for the estimations to be valid, the number of instruments must be less than or equal to the number of groups). The $p$-value of the Arellano-Bond test for stationarity in the second lag (Arellano-Bond AR (2)) and the p-value of the Hansen test for overidentifying restriction (Hansen) are reported in the last two rows of the table.

\begin{tabular}{|c|c|c|c|c|c|c|c|c|}
\hline \multirow[t]{2}{*}{ Variable } & \multicolumn{2}{|c|}{$\begin{array}{c}\text { Lender Account } \\
\text { Growth }\end{array}$} & \multicolumn{2}{|c|}{$\begin{array}{c}\text { Borrower Account } \\
\text { Growth }\end{array}$} & \multicolumn{2}{|c|}{$\begin{array}{l}\text { Lending } \\
\text { Transaction } \\
\text { Growth }\end{array}$} & \multicolumn{2}{|c|}{$\begin{array}{c}\text { Borrowing } \\
\text { Transaction } \\
\text { Growth }\end{array}$} \\
\hline & Model 1 & Model 2 & Model 1 & Model 2 & Model 1 & Model 2 & Model 1 & Model 2 \\
\hline CONSTANT & $\begin{array}{l}-0.089^{* * *} \\
(-0.008)\end{array}$ & $\begin{array}{l}-0.093^{* * *} \\
(-0.01)\end{array}$ & $\begin{array}{c}0.036 \\
(-0.104)\end{array}$ & $\begin{array}{c}0.057 \\
(-0.102)\end{array}$ & $\begin{array}{l}-0.109^{* *} \\
(-0.054)\end{array}$ & $\begin{array}{l}-0.088 \\
(-0.058)\end{array}$ & $\begin{array}{c}-0.113 \\
(-0.075)\end{array}$ & $\begin{array}{c}-0.116 \\
(-0.074)\end{array}$ \\
\hline $\begin{array}{l}\text { One-Period Lag } \\
\text { of RFR }\end{array}$ & $\begin{array}{c}0.001 \\
(-0.057)\end{array}$ & $\begin{array}{l}-0.018 \\
(-0.06)\end{array}$ & $\begin{array}{c}0.015 \\
(-0.096)\end{array}$ & $\begin{array}{l}-0.013 \\
(-0.088)\end{array}$ & $\begin{array}{l}0.026 \\
(-0.06)\end{array}$ & $\begin{array}{l}-0.001 \\
(-0.06)\end{array}$ & $\begin{array}{l}-0.004 \\
(-0.067)\end{array}$ & $\begin{array}{l}-0.023 \\
(-0.07)\end{array}$ \\
\hline RFMR & $\begin{array}{l}-0.532^{* *} \\
(-0.203)\end{array}$ & $\begin{array}{l}-0.619^{* *} \\
(-0.276)\end{array}$ & $\begin{array}{l}-0.870^{* * *} \\
(-0.271)\end{array}$ & $\begin{array}{c}-1.167^{* * *} \\
(-0.38)\end{array}$ & $\begin{array}{l}-0.497^{* * *} \\
(-0.157)\end{array}$ & $\begin{array}{l}-0.600^{* * *} \\
(-0.148)\end{array}$ & $\begin{array}{l}-0.579^{* * *} \\
(-0.118)\end{array}$ & $\begin{array}{c}-0.652^{* * *} \\
(-0.154)\end{array}$ \\
\hline$S M B$ & & $\begin{array}{l}0.316^{* *} \\
(-0.135)\end{array}$ & & $\begin{array}{l}0.251^{*} \\
(-0.14)\end{array}$ & & $\begin{array}{c}0.306 \\
(-0.281)\end{array}$ & & $\begin{array}{l}0.356^{* *} \\
(-0.151)\end{array}$ \\
\hline$H M L$ & & $\begin{array}{c}0.228 \\
(-0.164)\end{array}$ & & $\begin{array}{c}-0.562 \\
(-0.543)\end{array}$ & & $\begin{array}{c}0.268^{*} \\
(-0.145)\end{array}$ & & $\begin{array}{l}0.284^{* * *} \\
(-0.093)\end{array}$ \\
\hline FINTECH & $\begin{array}{c}0.165 \\
(-0.825)\end{array}$ & $\begin{array}{c}0.112 \\
(-0.822)\end{array}$ & $\begin{array}{c}-3.981 \\
(-3.369)\end{array}$ & $\begin{array}{l}-2.742 \\
(-2.533)\end{array}$ & $\begin{array}{c}1.462 \\
(-2.355)\end{array}$ & $\begin{array}{c}1.493 \\
(-2.245)\end{array}$ & $\begin{array}{l}-0.801 \\
(-1.611)\end{array}$ & $\begin{array}{l}-0.972 \\
(-1.671)\end{array}$ \\
\hline BIG_FINTECH & $\begin{array}{l}-1.234 \\
(-1.08)\end{array}$ & $\begin{array}{l}-1.207 \\
(-1.135)\end{array}$ & $\begin{array}{l}-3.198 \\
(-7.257)\end{array}$ & $\begin{array}{l}-8.235 \\
(-9.745)\end{array}$ & $\begin{array}{l}-5.011 \\
(-7.301)\end{array}$ & $\begin{array}{l}-3.296 \\
(-7.572)\end{array}$ & $\begin{array}{l}-3.242 \\
(-7.412)\end{array}$ & $\begin{array}{l}-1.687 \\
(-6.803)\end{array}$ \\
\hline MED_FINTECH & $\begin{array}{c}0.731 \\
(-3.334)\end{array}$ & $\begin{array}{c}0.735 \\
(-3.266)\end{array}$ & $\begin{array}{c}17.5 \\
(-11.597)\end{array}$ & $\begin{array}{c}16.231 \\
(-12.102)\end{array}$ & $\begin{array}{c}1.279 \\
(-7.261)\end{array}$ & $\begin{array}{l}-1.514 \\
(-5.092)\end{array}$ & $\begin{array}{c}8.305 \\
(-5.976)\end{array}$ & $\begin{array}{c}6.931 \\
(-5.559)\end{array}$ \\
\hline Groups & 39 & 39 & 39 & 39 & 39 & 39 & 39 & 39 \\
\hline Instruments & 14 & 16 & 14 & 16 & 14 & 16 & 14 & 16 \\
\hline $\begin{array}{l}\text { Arellano-Bond } \\
\text { AR (2) }\end{array}$ & 0.298 & 0.317 & 0.0992 & 0.155 & 0.43 & 0.404 & 0.142 & 0.172 \\
\hline Hansen & 0.178 & 0.149 & 0.216 & 0.214 & 0.215 & 0.147 & 0.223 & 0.156 \\
\hline
\end{tabular}


This page is intentionally left blank 